\title{
Teaching Video NeuroImages: Ictal vomiting in a child
}

Gewalin Aungaroon, MD, and Marissa Vawter-Lee, MD

Neurolog ${ }^{\circledR}$ 2018;91:e1836-e1837. doi:10.1212/WNL.0000000000006479
Correspondence

Dr. Aungaroon

Gewalin.aungaroon@

cchmc.org

Figure MRI of polymicrogyria

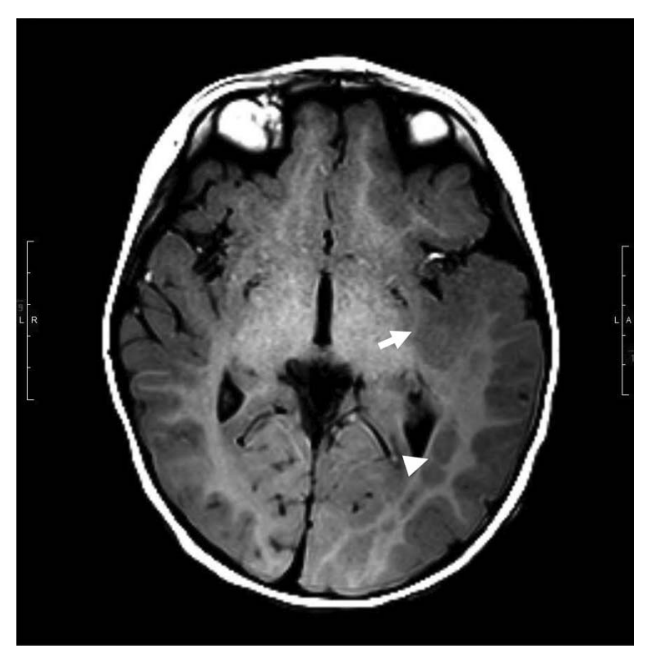

T1-weighted MRI scan shows cortical thickening and indistinction of the margin between gray and white matter in the left temporal lobe, posterior insular cortex, and temporal operculum (arrow). The nodular areas of gray matter along the left lateral ventricle occipital horn were compatible with gray matter heterotopia (arrowhead).

A 22-month-old boy presented with repetitive vomiting. The vomiting was occasionally associated with behavioral arrest, right arm jerking, and rightward head deviation. Video EEG revealed ictal vomiting localized to the left temporal head region (video 1). The MRI showed left hemisphere polymicrogyria, particularly in the left temporal lobe (figure). The seizures remained intractable despite multiple antiepileptic medications (levetiracetam, oxcarbazepine, and lacosamide). Ictal vomiting is a rare seizure semiology with a few distinctive features. ${ }^{1}$ It is reported in $2.7 \%$ of children and hypothesized to be associated with insular cortex involvement during a seizure. ${ }^{2,3}$

\section{Acknowledgment}

The authors thank Jason Buroker, Cincinnati Children's Hospital Medical Center, for technical support.

\section{MORE ONLINE}

\section{- Video}

$\rightarrow$ Teaching slides

links.lww.com/WNL/A734 


\section{Study funding}

No targeted funding reported.

\section{Disclosure}

The authors report no disclosures relevant to the manuscript. Go to Neurology.org/ $\mathrm{N}$ for full disclosures.

\section{References}

1. Kramer RE, Luders H, Goldstick LP, et al. Ictus emeticus: an electroclinical analysis. Neurology 1988;38:1048-1052.

2. Catenoix H, Isnard J, Guenot M, Petit J, Remy C, Mauguiere F. The role of the anterior insular cortex in ictal vomiting: a stereotactic electroencephalography study. Epilepsy Behav 2008;13:560-563.

3. Panayiotopoulos CP. Vomiting as an ictal manifestation of epileptic seizures and syndromes. J Neurol Neurosurg Psychiatry 1988;51:1448-1451.

Appendix 1. Author contributions

\begin{tabular}{|c|c|c|c|}
\hline Name & Location & Role & Contribution \\
\hline $\begin{array}{l}\text { Gewalin } \\
\text { Aungaroon, } \\
\text { M.D. }\end{array}$ & $\begin{array}{l}\text { Cincinnati Children's Hospital } \\
\text { Medical Center, Cincinnati, OH }\end{array}$ & Author & $\begin{array}{l}\text { Conception and design of the study; collection, analysis, and interpretation of the data; } \\
\text { drafting and critical revision of the article; generation/collection of the figures }\end{array}$ \\
\hline $\begin{array}{l}\text { Marissa } \\
\text { Vawter-Lee, } \\
\text { M.D. }\end{array}$ & $\begin{array}{l}\text { Cincinnati Children's Hospital } \\
\text { Medical Center, Cincinnati, OH }\end{array}$ & Author & Collection of the data; drafting and critical revision of the article \\
\hline
\end{tabular}




\title{
Neurology
}

\author{
Teaching Video NeuroImages: Ictal vomiting in a child \\ Gewalin Aungaroon and Marissa Vawter-Lee \\ Neurology 2018;91;e1836-e1837 \\ DOI 10.1212/WNL.0000000000006479
}

This information is current as of November 5, 2018

\section{Updated Information \& Services}

\section{References}

Subspecialty Collections

\section{Permissions \& Licensing}

Reprints including high resolution figures, can be found at: http://n.neurology.org/content/91/19/e1836.full

This article cites 3 articles, 2 of which you can access for free at: http://n.neurology.org/content/91/19/e1836.full\#ref-list-1

This article, along with others on similar topics, appears in the following collection(s):

All Clinical Neurology

http://n.neurology.org/cgi/collection/all_clinical_neurology All Education

http://n.neurology.org/cgi/collection/all_education

All Epilepsy/Seizures

http://n.neurology.org/cgi/collection/all_epilepsy_seizures

EEG; see Epilepsy/Seizures

http://n.neurology.org/cgi/collection/eeg_see_epilepsy-seizures

Epilepsy semiology

http://n.neurology.org/cgi/collection/epilepsy_semiology

Information about reproducing this article in parts (figures,tables) or in its entirety can be found online at:

http://www.neurology.org/about/about_the_journal\#permissions

Information about ordering reprints can be found online:

http://n.neurology.org/subscribers/advertise

Neurology ${ }^{\circledR}$ is the official journal of the American Academy of Neurology. Published continuously since 1951, it is now a weekly with 48 issues per year. Copyright @ 2018 American Academy of Neurology. All rights reserved. Print ISSN: 0028-3878. Online ISSN: 1526-632X.

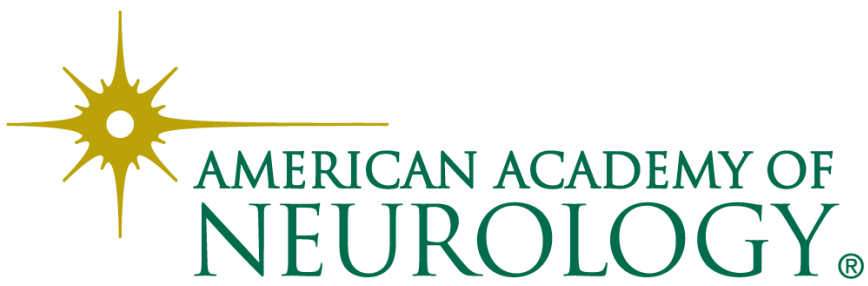

